\title{
PENGARUH BAGI HASIL DAN PENDAPATAN PER KAPITA TERHADAP PENINGKATAN DANA PIHAK KETIGA
}

\author{
Lina Marlina $^{1 *}$, Jajang Iskandar ${ }^{2}$ \\ ${ }^{1}$ Program Studi Ekonomi Syariah, Universitas Siliwangi, linamarlina@unsil.ac.id \\ ${ }^{2}$ Program Studi Ekonomi Syariah, Universitas Siliwangi, jajangiskandar@gmail.com
}

\begin{abstract}
The purpose of this study is to find out how profit sharing and per capita income affects on third party funds both partially and simultaneously. The research was conducted at Bank Jabar Banten Syariah KCP Singaparna period 2011 - 2013. In this study the authors used the correlational method with a quantitative approach. Data are gained through field research, using multiple regression analysis as the test tool. The results of the study show that profit sharing, per capita income and third party funds are fluctuatively increasing as well as decreasing; Profit Sharing partially has a significant effect on Third Party Funds; Per Capita income partially has a significant effect on Third Party Funds; Profit Sharing and Per Capita Income simultaneously have a significant effect on Third Party Funds at Bank Jabar Banten Syariah KCP Singaparna in the period 2011 - 2013.
\end{abstract}

Keywords: Profit Sharing, Per capita Income, Third-party funds, Islamic Bank.

\begin{abstract}
ABSTRAK
Tujuan dari penelitian ini untuk mengetahui bagaimana bagi hasil dan pendapatan per kapita mempengaruhi dana pihak ketiga baik secara parsial maupun simultan. Penelitian ini dilakukan di Bank Jabar Banten Syariah KCP Singaparna periode 2011 - 2013. Dalam penelitian ini penulis menggunakan metode korelasional dengan pendekatan kuantitatif. Data diperoleh melalui penelitian lapangan, menggunakan analisis regresi berganda sebagai alat uji. Hasil penelitian menunjukkan bahwa bagi hasil, pendapatan per kapita dan dana pihak ketiga berfluktuasi meningkat serta menurun; Bagi Hasil secara parsial memiliki pengaruh signifikan terhadap Dana Pihak Ketiga; Pendapatan per kapita secara parsial memiliki pengaruh signifikan terhadap Dana Pihak Ketiga; Bagi Hasil dan Pendapatan Per Kapita secara simultan memiliki pengaruh yang signifikan terhadap Dana Pihak Ketiga di Bank Jabar Banten Syariah KCP Singaparna pada periode 2011 - 2013.
\end{abstract}

Kata kunci: Bagi Hasil, Pendapatan per kapita, Dana Pihak Ketiga, Bank Syariah.

\footnotetext{
1 *Penulis korenpondensi, email: linamarlina@unsil.ac.id
} 


\section{PENDAHULUAN}

Bank Islam atau bank syariah adalah bank yang beroperasi dengan tidak mengandalkan pada bunga. Bank Islam yang disebut juga dengan bank tanpa bunga adalah lembaga keuangan/perbankan yang operasional dan produknya dikembangkan berlandasan pada AlQuran dan Al-Hadist Nabi SAW (Muhammad, 2014). Kegiatan operasional bank syariah di Indonesia dimulai pada tahun 1992 melalui pendirian PT Bank Muamalat Indonesia Tbk. Perkembangan bank syariah berjalan lebih lambat dibandingkan dengan bank konvensional. Hal ini karena indikatornya terletak pada marketshare perbankan syariah di Indonesia tahun 2014 masih sekitar 3\% dari total marketshare perbankan yang ada di Indonesia. Marketshare perbankan syariah masih memiliki porsi yang kecil dan hal ini pula yang membuat perbankan syariah terkesan lambat. Dalam beberapa tahun terakhir ditargetkan marketshare perbankan syariah di Indonesia bisa mencapai 5\%, namun belum tercapai.

Hingga tahun 2013, jumlah bank syariah di Indonesia dapat ditunjukkan dalam tabel 1 berikut:

Tabel 1. Perkembangan Kantor Bank Syariah Tahun 2013

\begin{tabular}{|l|l|l|l|l|l|}
\hline \multicolumn{1}{|c|}{ Keterangan } & \multicolumn{1}{|c|}{2009} & \multicolumn{1}{|c|}{2010} & \multicolumn{1}{|c|}{2011} & \multicolumn{1}{c|}{2012} & 2013 \\
\hline Jumlah Bank & & & & & \\
\hline Bank Umum Syariah (BUS) & 11 & 11 & 11 & 11 & 11 \\
\hline Unit Usaha Syariah (UUS) & 25 & 23 & 24 & 24 & 24 \\
\hline Bank Pembiayaan Rakyat Syariah & 139 & 150 & 155 & 158 & 160 \\
\hline
\end{tabular}

Sumber: Stastistik Perbankan Syariah Tahun 2013.

Perkembangan bank syariah diantaranya dipengaruhi oleh kinerja. Salah satu aspek yang memegang peranan penting dalam kinerja bank adalah kemampuan bank tersebut dalam menghimpun dana pihak ketiga berupa tabungan, deposito, ataupun giro. Dalam hal penghimpun dana pihak ketiga, bank syariah menggunakan instrumen nisbah bagi hasil dimana ketentuan keuntungan didasarkan pada jumlah keuntungan yang diperoleh. Semakin besar tingkat keuntungan yang diperoleh akan semakin besar nominal yang diberikan kepada nasabah.

Persaingan dunia perbankan secara umum dan perbankan syariah secara khusus, menuntut bank syariah untuk meningkatkan kinerja bank dalam menghimpun dana pihak ketiga. Semakin besar dana pihak ketiga yang dihimpun oleh bank syariah akan semakin memperkuat fungsi bank sebagai penyalur dana yang bertujuan memperoleh profit yang tinggi, namun persaingan perbankan dalam menarik nasabah untuk menyimpan atau berinvestasi tidaklah mudah. Hal ini disebabkan karena pendapatan per kapita masyarakat yang sangat rendah menyebabkan mereka lebih mengalokasikan pendapatannya untuk kepentingan konsumsi dari pada menabung atau berinvestasi. Selain itu masyarakat pada umumnya lebih konsumtif dari pada menabung dan berinvestasi di bank. Dengan anggapan bahwa mengkonsumsi barangbarang lebih memuaskan kebutuhan dibandingkan dengan menabungan. Mereka akan menabung atau berinvestasi jika diberikan bunga/ bagi hasil sebagai imbalan bagi penghematannya. Maka semakin tinggi tingkat suku bunga/ bagi hasil akan semakin besar tabungan yang disimpan di bank, dan besarnya tabungan nasabah yang disimpan di bank akan mempengaruhi peningkatan terhadap dana pihak ketiga. 
Penelitian ini hendak mengetahui bagaimana pengaruh bagi hasil dan pendapatan perkapita terhadap peningkatan dana pihak ketiga. Penelitian dilaksanakan di Bank Jabar Banten Syariah KCP Singaparna Tasikmalaya periode 2011 - 2013.

\section{LITERATUR REVIEW}

\section{Bagi Hasil}

Bagi hasil merupakan suatu sistem yang meliputi tata cara pembagian hasil usaha antara penyedia dana dengan pengelola dana (Muhammad, 2014). Di dalam kegiatan usaha diperjanjikan adanya pembagian hasil atas keuntungan yang akan di dapat antara kedua belah pihak atau lebih bagi hasil dalam sistem perbankan syariah merupakan ciri khusus yang ditawarkan kepada masyarakat, dan di dalam aturan syariah yang berkaitan dengan pembagian hasil usaha harus ditentukan terlebih dahulu pada awal terjadinya kontrak ( $\mathrm{akad}$ ). Besarnya penentuan porsi bagi hasil antara kedua belah pihak ditentukan sesuai dengan kesepakatan bersama, dan dibuat dengan dasar kerelaan ('an-tara'dhin) di masing-masing pihak tanpa adanya unsur paksaan. Bagi hasil merupakan hasil ketentuan keuntungan ditentukan besar kecilnya dari hasil suatu usaha. Pembagian porsi keuntungan dihitung sesuai nisbah bagi hasil didasarkan pada jumlah keuntungan yang diperoleh. Semakin besar tingkat keuntungan yang diperoleh semakin besar jumlah pembagian laba yang dibagikan kepada nasabah (Eliza Fitriah $\&$ Nur S. Buchori, t.t.).

Salah satu faktor utama bagi hasil adalah memperoleh hasil tabungan/ investasi. Besar kecilnya hasil investasi dipengaruhi oleh banyak faktor. Faktor pengaruh tersebut ada yang berdampak langsung dan ada yang tidak langsung. Diantara faktor - faktor langsung (direct factors) yang mempengaruhi perhitungan bagi hasil adalah investment rate, jumlah dana yang tersedia, dan nisbah bagi hasil (profit sharing ratio). Adapun faktor tidak langsung yang mempengaruhi bagi hasil diantaranya penentuan butir-butir pendapatan dan biaya, serta Kebijakan akunting (prinsip dan metode akuntansi) (Muhammad, 2014).

\section{Pendapatan PerKapita}

Pendapatan perkapita merupakan indikator yang digunakan secara luas untuk mengukur tingkat kesejahteraan suatu masyarakat. Dengan demikian, tingkat kesejahteraan suatu masyarakat diukur dengan menggunakan indikator pendapatan per kapita. Pendapatan perkapita merupakan ratarata pendapatan untuk setiap individu atau untuk setiap anggota keluarga yang diperoleh dengan membandingkan rata-rata pendapatan rumah tangga perbulan dengan jumlah anggota keluarga pada suatu wilayah kota tertentu (Safarul Aufa, t.t.). Pendapatan per kapita adalah pendapatan rata-rata penduduk (Lincolin Arsyad, 2004). Oleh karena itu untuk pendapatkan per kapita diperoleh dengan cara membagi pendapatan nasional dengan jumlah penduduk pada periode tertentu. Pendapatan per kapita yang merupakan salah satu prestasi ekonomi sangat erat kaitannya dengan pertambahan penduduk, sehingga apabila pertambahan pendapatan nasional lebih besar dari pada pertambahan penduduk maka tingkat pendapatan per kapita penduduk meningkat. Sebaliknya apabila pertambahan pendapatan nasional lebih kecil 
dari pertambahan penduduk maka pendapatan per kapita mengalami penurunan. Untuk mempertahankan tingkat per kapita relatif perlu dicapai tingkat pertambahan nasional yang sama dengan tingkat pertambahan penduduk. Pendapatan nasional dan pendapatan per kapita akan naik apabila produktivitas perkapita mengalami kenaikan. Untuk menaikkan produktivitas per kapita biperlukan perubahan-perubahan dalam perekonomian misalnya perubahan struktur ekonomi, teknik produksi, sruktur produksi dan masyarakat statis berkembang menjadi masyarakat dinamis.

\section{Dana Pihak Ketiga (DPK)}

Dana pihak ketiga merupakan dana yang dihimpun oleh bank yang berasal dari masyarakat. Sumber dana dari masyarakat merupakan sumber dana yang terpenting bagi kegiatan operasi bank dan merupakan ukuran keberhasilan bank jika mampu membiayai operasinya dari sumber dana ini. Dana pihak ketiga adalah dana masyarakat dipercayakan kepada bank dilakukan menurut syarat-syarat tertentu yang telah disepakati, dalam bentuk giro, deposito, dan tabungan atau bentuk lainnya yang dipersamakan dengan itu (Kasmir, 2004). Penghimpunan dana dari masyarakat dapat dikatakan relatif lebih mudah jika dibandingkan dengan sumber dana lainnya, selain itu dapat dilakukan secara efektif dengan memberikan nisbah yang relatif lebih tinggi dan memberikan berbagai fasilitas yang menarik lainnya seperti hadiah dan pelayanan yang memuaskan. Bank syariah dalam menghimpun dana dari masyarakat atau dana pihak ketiga, dibagi menjadi tiga bentuk yaitu: a) Titipan (wadiah), merupakan simpanan yang dijamin keamanan dan pengembalikannya (guaranteed deposit) tetapi tanpa memperoleh imbalan atau keuntungan; b) partisipasi modal berbagi hasil dan berbagi resiko (non guaranted account) untuk investasi umum (general investasment account/ mudharabah mutlaqah) dimana bank akan membayar bagian keuntungan secara proposional dengan portofolio yang didanai dengan modal tersebut; c) investasi khusus (special investment account/ mudharabah muqayyadah), dimana bank bertindak sebagai manajer investasi untuk memperoleh fee. Jadi bank tidak ikut berinvestasi sedangkan investor sepenuhnya mengambil risiko atas investasi itu. (Muhammad, 2014).

\section{Hubungan Bagi Hasil dengan Dana Pihak Ketiga}

Bagi hasil merupakan suatu sistem yang meliputi tata cara pembagian hasil usaha antara penyedia dana dengan pengelola dana (Muhammad, 2014). Dalam Islam, yang berkaitan dengan pembagian hasil usaha harus ditentukan pada awal terjadinya kontrak ( $a k a d)$. Besarnya penentuan porsi bagi hasil antara kedua belah pihak ditentukan sesuai dengan kesepakatan bersama, dan dibuat dengan dasar kerelaan ('an-tarâdhin) di masingmasing pihak tanpa adanya unsur paksaan. Angka bagi hasil merupakan angka hasil negosiasi shahibul mâl dan mudharib dengan mempertimbangkan potensi dari proyek yang akan dibiayai. Faktor-faktor penentu tingkat bagi hasil adalah unsur "iwad" (counter-value) dari proyek itu sendiri, yaitu risiko (ghurmi), nilai tambah dari kerjadian usaha (kasb), dan tanggungan (dhaman). Porsi bagi hasil untuk bank syariah digunakan untuk membiayai aktivitas operasional bank sekaligus laba wajar 
bank itu sendiri. Besarnya biaya tersebut tergantung pada tingkat efektivitas manajemen masing-masing bank. Dari kalkulasi tersebut bagian untuk bank syariah juga dipublikasikan dalam bentuk persentase (equivalent rate).

Menurut marshall, Suku bunga ditentukan oleh interaksi kurva penawaran dan permintaan tabungan. Marshall, beranggapan bahwa sisi penawaran merupakan pemberian imbalan kepada nasabah dengan memberikan tingkat suku bunga, suku bunga merupakan balas jasa atas pengorbanan tabungan atau pengorbanan menunggu, dan dari Sisi permintaan merupakan produktivitas margin dan suku bunga. Jika penawaran tabungan lebih besar dari permintaan tabungan untuk investasi, maka suku bunga akan turun dan investasi akan meningkat sampai tercapai keseimbanganan antara tabungan dan investasi. Sebaliknya, apabila permintaan tabungan, maka suku bunga akan naik dan investasi akan turun sampai tercapai tingkat keseimbangan baru (Muhamad, 2001). Dengan demikian, jika tabungan banyak diminati oleh masyarakat maka tingkat suku bunga yang diberikan oleh bank akan besar.

Dalam perbankan syariah sistem keuntungan yang didapat adalah bagi hasil. Pendapatan bagi hasil yang diperoleh bank berasal dari hasil penetapan dana pihak ketiga melalui pembiayaan yang berakad jual beli (Muhammad, 2014). Hasil dari pendapat tersebut dibagihasilkan kepada nasabah pemilik dana (deposan). Membagihasilkan pendapatan tersebut dilihat dari perbandingan antara jumlah dana yang dikelola tabungan dengan jumlah pembiayaan yang disalurkan. Apabila jumlah pembiayaan lebih kecil dari total dana masyarakat, maka pendapatan tersebut seluruhnya dibagihasilkan antara nasabah dengan bank. Sebaliknya jika pembiayaan jumlahnya lebih besar dari total dana masyarakat, maka modal bank juga harus memperoleh bagian pendapatan. Nejatullah Siddiqi melakukan analisis terhadap perilaku bagi hasil terhadap kondisi stabilitas ekonomi, bahwa: "the introduction of ratios of profit sharing to replace rate of interest will not destabilize the economy and that the change in the entrepreneural profit will not get communicated back all along the line" (Muhamad, 2001).

Pernyataan ini menetapkan bahwa sistem ekonomi berdasarkan bagi hasil akan menjamin alokasi sumber ekonomi yang lebih baik dan terjadinya distribusi pendapatan yang lebih sesuai. Analisis terhadap persoalan peran bagi hasil terhadap pencapaian stabilitas ekonomi harus dengan menggunakan pendekatan analisis keseimbangan (equilibrium). Mekanisme analisis keseimbangan menyajikan bagaimana mekanisme penentuan supply dan deman atas tabungan.

\section{Hubungan Pendapatan Per kapita dengan Dana Pihak Ketiga}

Pendapatan perkapita merupakan rata-rata pendapatan untuk setiap individu atau untuk setiap anggota keluarga yang diperoleh dengan membandingkan rata-rata pendapatan rumah tangga perbulan dengan jumlah anggota keluarga pada suatu wilayah kota tertentu (Safarul Aufa, t.t.:66). Menurut Lincolin Arsyad Pendapatan per kapita adalah pendapatan rata-rata penduduk (Lincolin Arsyad, 2004). Oleh karena itu pendapatkan per kapita diketahui dengan cara membagi pendapatan nasional dengan jumlah penduduk pada periode tertentu. Pendapatan 
per kapita yang merupakan salah satu prestasi ekonomi sangat erat kaitannya dengan pertambahan penduduk, sehingga apabila pertambahan pendapatan nasional lebih besar dari pada pertambahan penduduk maka tingkat pendapatan per kapita penduduk meningkat. Sebaliknya apabila pertambahan pendapatan nasional lebih kecil dari pertambahan penduduk maka pendapatan per kapita mengalami penurunan. Untuk mempertahankan tingkat per kapita relatif perlu dicapai tingkat pertambahan nasional yang sama dengan tingkat pertambahan penduduk. Pendapatan nasional dan pendapatan per kapita itu sendiri akan naik apabila produktivitas perkapita mengalami kenaikan. Untuk menaikkan produktivitas per kapita diperlukan adanya perubahan-perubahan dalam perekonomian misalnya perubahan struktur ekonomi, teknik produksi, sruktur produksi dan masyarakat statis berkembang menjadi masyarakat dinamis.

Pendapatan per kapita merupakan pendapatan yang sering dilakukan oleh rumah tangga seperti konsumsi dan tabungan. Menurut Keynes, besarnya tabungan yang dilakukan oleh rumah tangga tidak tergantung kepada tinggi rendahnya suku bunga, tetapi tergantung kepada besar kecilnya tingkat pendapatan rumah tangga. Makin besar jumlah pendapatan yang diterima oleh suatu rumah tangga, makin besar pula jumlah tabungan yang akan dilakukan oleh rumah tangga dan sebaliknya makin kecil jumlah pendapatan yang diterima oleh suatu rumah tangga, maka semakin kecil pula jumlah tabungannya (wijaya, t.t.). Dan menurut Putu Semaradana bahwa semakin tinggi pendapatan, apabila diikuti oleh sikap berhemat maka akan memperbesar tingkat tabungan (Putu Semaradana, t.t.). Oleh karna itu, jika pendapatan per kapitanya tinggi maka kecenderungan mengonsumsi semakin rendah sehingga tingkat tabungan semakin tinggi. Dengan demikian pendapatan per kapita mempunyai pengaruh terhadap dana pihak ketiga karena semakin besar pendapatan seseorang maka semakin besar peluang untuk menyimpan/ menabung dananya di bank.

Penelitian tentang faktor-faktor yang mempengaruhi dana pihak ketiga telah banyak dilakukan. Diantaranya (Wibowo, 2011) meneliti faktor yang mempengaruhi jumlah dana pihak ketiga (DPK) pada bank syariah di Indonesia, dengan variabel bebas terdiri dari nisbah (profit sharing ratio), tingkat pembiayaan bermasalah (Non Performing Financing/NPF), dan pendapatan nasional riil (GDP riil) dengan tiga sampel penelitian yaitu Bank Muamalat Indonesia, Bank Syariah Mandiri dan Bank Mega Syariah. Hasil penelitian menunjukkan bahwa variabel nisbah (profit sharing ratio) tidak berpengaruh secara signifikan terhadap pertumbuhan dana pihak ketiga pada Bank Syariah di Indonesia; variabel tingkat pembiayaan bermasalah (Non Performing Financing/NPF) juga tidak berpengaruh secara signifikan terhadap pertumbuhan dana pihak ketiga pada Bank Syariah di Indonesia; dan pendapatan nasional riil (GDP riil) yang mencerminkan kemampuan untuk menabung menunjukkan bahwa tidak adanya hubungan yang signifikan terhadap pertumbuhan dana pihak ketiga pada Bank Syariah di Indonesia.

Penelitian (Friska Diaz Sekar Puri, 2013) mengkaji faktor-faktor yang mempengaruhi penghimpunan Dana Pihak Ketiga (DPK) Perbankan Syariah di Indonesia dengan menggunakan data empiris selama periode 2008-2011. Penelitian ini dimaksudkan untuk 
malihat faktor-faktor apa saja yang mempengaruhi permintaan masyarakat untuk menyimpan/menginvestasikan dananya dalam perbankan syariah. Penelitian tersebut menguji 4 variabel yaitu, Suku Bunga (SBI), Nisbah bagi hasil (nisbah), Pendapatan Masyarakat (PDB) dan jumlah Kantor perbankan syariah. Berdasarkan estimasi persamaan, didapatkan informasi bahwa masyarakat menyimpan dananya di perbankan syariah dipengaruhi secara signifikan oleh Suku Bunga (SBI). Ini berarti nasabah yang ada di bank syariah sebagian besar adalah nasabah rasional. Pengaruh pendapatan juga memberikan hasil yang signifikan terhadap penghimpunan dana pihak ketiga perbankan syariah di Indonesia. Hal ini juga menunjukkan bahwa nasabah perbankan syariah juga mempunyai motif transaksional.

Penelitian (Yuliana, 2009) tentang pengaruh bagi hasil, inflasi, Produk Domestik Bruto, dan Return on Investment (ROI) terhadap Dana Pihak Ketiga Perbankankan Syariah Tahun 2006 - 2008, dengan populasi selurub bank yang berbasis syariah. Hasil penelitian menunjukkan bahwa secara parsial variabel bagi hasil berpengaruh positif dan signifikan terhadap Dana Pihak Ketiga Perbankan Syariah tahun 2006 - 2008; variabel ROI berpengaruh negatif dan signifikan terhadap Dana Pihak Ketiga Perbankan Syariah tahun 2006 - 2008; variabel inflasi berpengaruh negatif dan tidak signifikan terhadap Dana Pihak Ketiga Perbankan Syariah tahun 2006 - 2008. Pada uji F menunjukkan bahwa variabel independen bagi hasil, inflasi, Produk Domestik Bruto, dan Return on Investment (ROI) berpengaruh positif dan signifikan terhadap Dana Pihak Ketiga Perbankankan Syariah Tahun 2006 - 2008.

Dari beberapa hasil penelitian diatas diketahui bahwa faktor-faktor yang mempengaruhi Dana Pihak Ketiga diantaranya bagi hasil, suku bunga Indonesia (SBI), pendapatan masyarakat atau Produk Domestik Bruto (PDB), inflasi, dan Return on Investment (ROI). Dalam penelitian ini hanya variabel Bagi Hasil dan Pendapatan Perkapita yang penulis angkat sebagai variabel bebas. Dengan demikian paradigma penelitian dapat digambarkan sbb:

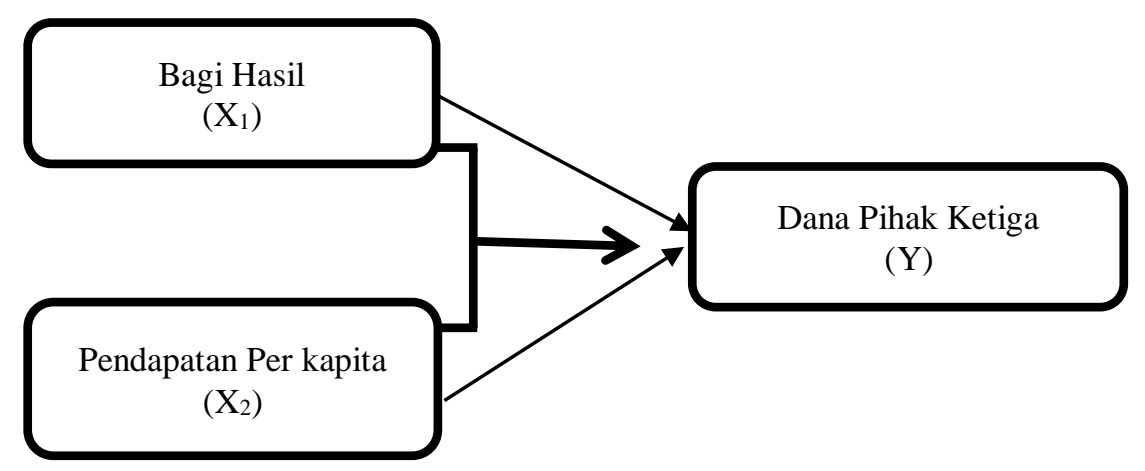

Gambar 1. Paradigma penelitian

Dengan hipotesis penelitian sbb: Secara parsial:

$\mathrm{H}_{01}$ : Bagi hasil secara parsial tidak mempunyai pengaruh terhadap jumlah dana pihak ketiga. 
$\mathrm{H}_{\mathrm{a} 1}$ : Bagi hasil secara parsial mempunyai pengaruh terhadap jumlah dana pihak ketiga.

$\mathrm{H}_{02}$ : $\quad$ Pendapatan per kapita secara parsial tidak mempunyai pengaruh terhadap jumlah dana pihak ketiga.

$\mathrm{H}_{\mathrm{a} 2}$ : $\quad$ Pendapatan per kapita secara parsial mempunyai pengaruh terhadap jumlah dana pihak ketiga.

Secara simultan:

$\mathrm{H}_{\mathrm{o}}$ : $\quad$ Bagi hasil dan pendapatan per kapita secara simultan tidak mempunyai pengaruh terhadap jumlah dana pihak ketiga.

$\mathrm{H}_{\mathrm{a} 3}$ : $\quad$ Bagi hasil dan pendapatan per kapita secara simultan mempunyai pengaruh terhadap jumlah dana pihak ketiga.

\section{METODE}

Penelitian ini menggunakan metode penelitian korelasional dengan pendekatan kuantitatif. Metode korelasional adalah metode yang digunakan untuk menganalisis sejumlah variabel-variabel pada suatu faktor berkaitan dengan variabel-variabel satu atau lebih faktor lain berdasarkan pada koefisien korelasi. Sedangkan metode penelitian kuantitatif dapat diartikan sebagai metode penelitian yang digunakan untuk meneliti pada populasi atau sampel tertentu, pengumpulan data menggunakan instrumen penelitian, analisis data kuantitatif dengan tujuan untuk menguji hipotesis yang telah ada (Sugiyono, 2013). Dalam hal ini, metode korelasional dengan pendekatan kuantitatif merupakan metode untuk mengetahui sejauh mana hubungan antara Bagi Hasil dan Pendapatan Per Kapita terhadap Dana Pihak Ketiga pada Bank Jabar Banten Syariah KCP Singaparna dengan cara mengumpulkan data, mengelola, menganalisis dan menginterpretasikan data dalam pengujian hipotesis statistik.

Variabel independen dalam penelitian ini yaitu Bagi hasil $\left(\mathrm{X}_{1}\right)$ dan Pendapatan Perkapita (X2). Data dalam variabel nisbah bagi bagi hasil mulai dari bulan Januari 2011 sampai Desember 2013, data disajikan perbulan yang diperoleh dari Bank Jabar Banten Syariah KCP Singaparna. Pendapatan per kapita $\left(\mathrm{X}_{2}\right)$ adalah pendapatan rata-rata penduduk di suatu wilayah tertentu kabupaten Tasikmalaya. Data dalam variabel pendapatan per kapita ini dari Januari 2011 sampai Desember 2013 perbulan yang diperoleh dari Badan Pusat Stastistik kabupaten Tasikmalaya. Adapun Variabel dependen dalam penelitian ini adalah dana pihak ketiga (Y) yaitu dana yang dihimpun oleh bank yang berasal dari masyarakat. Data dalam variabel ini dana pihak ketiga ini dari bulan Januari 2011 sampai Desember 2013 disajikan perbulan yang diperoleh Bank Jabar Banten Syariah KCP Singaparna.

Data dalam penelitian ini adalah data sekunder dan jenis data yang dipergunakan adalah data time series (runtutan waktu). Adapun teknik pengumpulan data dilakukan dengan studi dokumentasi. Teknik studi dokumentasi bersumber dari data sekunder yang berdasarkan pada laporan keuangan konsolidasi publikasi PT. Bank Jabar Banten syariah Cabang Tasikmalaya dan Badan Pusat stastistik (BPS). 
Untuk mengetahui pengaruh Nisbah Bagi Hasil dan Pendapatan Per Kapita terhadap Dana Pihak Ketiga, dalam penelitian ini mengunakan Analisis Regresi Berganda, dalam perhitungannya menggunakan metode statistik yang dibantu dengan program pengelolaan data statistik yaitu SPPS (Statistical Package for Social Science) versi 20.

Uji hipotesis akan dimulai dengan penetapan hipotesis operasional, penetapan tingkat signifikan, uji signifikan, kaidah keputusan dan penarikan kesimpulan.

Hipotesis operasional dalam penelitian ini adalah:

Ho $: \rho=0$ Tidak terdapat pengaruh yang signifikan antara Nisbah Bagi

Hasil dan Pendapatan per kapita secara parsial maupun simultan terhadap Dana Pihak Ketiga.

Ha : $\rho \quad$ \ 0 Terdapat pengaruh yang signifikan antara Nisbah Bagi Hasil dan Pendapatan per kapita secara parsial maupun simultan terhadap Dana Pihak Ketiga.

Tingkat signifikansi yang digunakan adalah $95 \%(\square=0,05)$ yang merupakan tingkat signifikansi yang sering digunakan dalam ilmu sosial yang menunjukkan kedua variabel mempunyai korelasi cukup nyata.

\section{HASIL DAN PEMBAHASAN}

\section{Bagi Hasil}

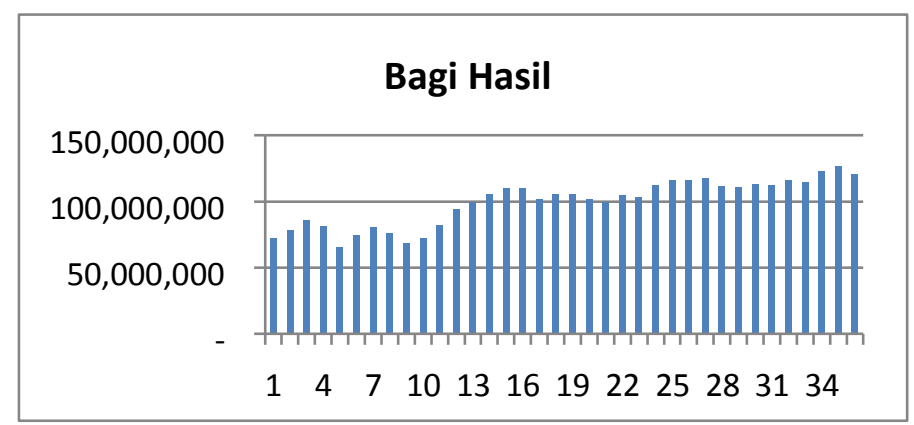

Gambar 2. Bagi Hasil Bank Jabar Banten Syariah pada periode 2011-2013

Berdasarakan gambar 2. di atas nampak bahwa Bagi Hasil di Bank Jabar Banten Syariah pada periode 2011-2013 mengalami fluktuasi selama kurun waktu pengamatan (observasi). Nilai bagi hasil paling tinggi yaitu di bulan November tahun 2013 dengan nilai 126.743.151, sedangkan Bagi Hasil paling rendah yaitu di bulan Mei tahun 2011 dengan nilai 65.768.451. 


\section{Pendapatan PerKapita}

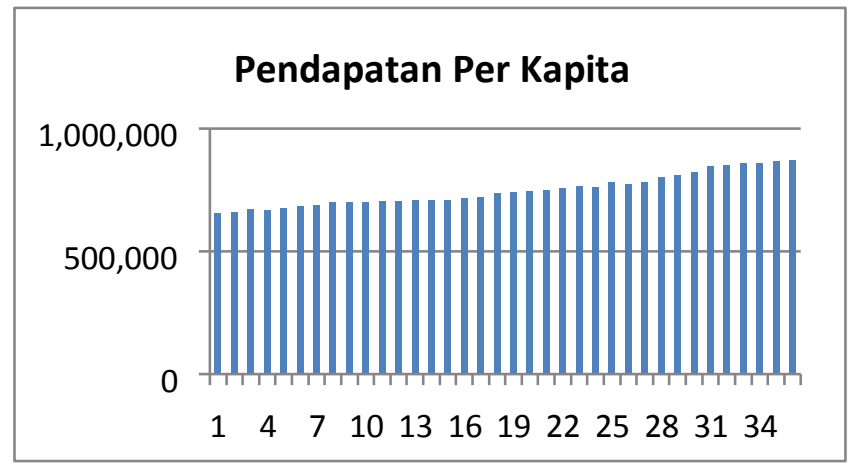

Gambar 3. Pendapatan Per Kapita

Berdasarkan gambar 3 Pendapatan Per Kapita yang diperoleh dari Badan Pusat Stastistik (BPS) Kab. Tasikmalaya Periode 2011-2013 mengalami fluktuasi kurun waktu pengamatan (observasi). Data Pendapatan Per Kapita paling besar yaitu di bulan Desember tahun 2013 dengan jumlah 870.426, sedangkan paling rendah yaitu bulan Januari 2011 dengan jumlah sebesar 655.083.

\section{Dana Pihak Ketiga}

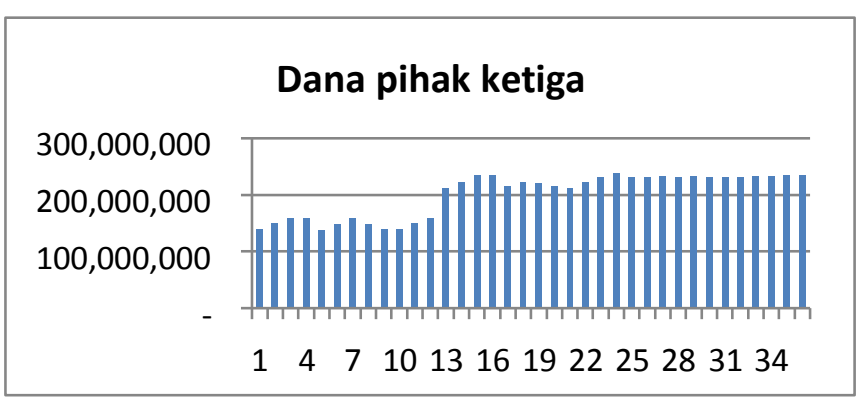

Gambar 4. Dana Pihak Ketiga Bank Jabar Banten Syariah KCP Singaparna periode 2011-2013

Berdasarkan gambar 4. Dana Pihak Ketiga yang berhasil dihimpun oleh Bank Jabar Banten Syariah KCP Singaparna periode 2011-2013, data DPK paling besar yaitu di bulan Desember tahun 2013 dengan jumlah sebesar 234.919.873, sedangkan jumlah paling sedikit yaitu dibulan Mei tahun 2011dengan jumlah sebesar 137.738.410.

\section{Uji Normalitas Data}

Tabel 2. Normalitas

One-Sample Kolmogorov-Smirnov Test

\begin{tabular}{|c|c|c|}
\hline & & $\begin{array}{l}\text { Unstandardized } \\
\text { Residual }\end{array}$ \\
\hline $\mathrm{N}$ & \multirow{3}{*}{ Mean } & 36 \\
\hline \multirow{2}{*}{$\begin{array}{l}\text { Normal } \\
\text { Parameters }^{\mathrm{a}, \mathrm{b}}\end{array}$} & & $0 \mathrm{E}-7$ \\
\hline & & 9893222,63784153 \\
\hline
\end{tabular}




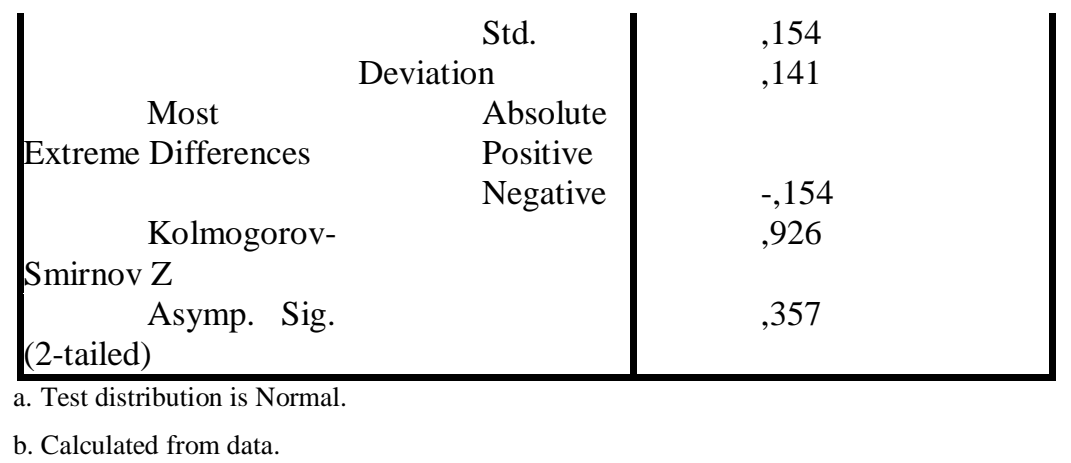

Berdasarkan hasil ouput pada table 2 di atas, nampak bahwa nilai asymp.sig (2-tailed) yaitu 0,357 . Jika dibandingkan dengan nilai alpha yang besarnya adalah 0,05 , maka yang dihasilkan di atas lebih besar dari pada nilai alpha $(0,357>0,05)$. sehingga dapat disimpulkan bahwa data yang diperoleh dinyatakan berdistribusi normal dan dapat dikatakan bahwa model regresi memenuhi asumsi normalitas sehingga data layak untuk digunakan.

\section{Regresi Berganda}

- Regresi Parsial X X $_{1}$ Bagi Hasil) terhadap Y (Dana Pihak Ketiga)

Tabel 3. Analisis Regresi $\left(X_{1}\right)$ Coefficients $^{\mathrm{a}}$

\begin{tabular}{|cc|c|c|c|}
\hline \multirow{2}{*}{ Model } & \multicolumn{2}{|c|}{ Unstandardized Coefficients } & $\begin{array}{c}\text { Standardized } \\
\text { Coefficients } \\
\end{array}$ \\
& & B & Std. Error & Beta \\
\hline \multirow{2}{*}{1} & (Constant) & $-133956136,543$ & 49646881,835 & \\
& BH & 448,585 & 66,130 &, 758 \\
\hline
\end{tabular}

a. Dependent Variable: DPK

Berdasarkan hasil perhitungan pada tabel 3 di atas atau tabel coefficients dapat disusun dalam bentuk persamaan regresi $\mathrm{Y}=-133956136,543+448,585 x$, konstanta $(\mathrm{a})=$ 133956136,543. Bila $X_{1}$ (bagi hasil) $=0$, maka dana pihak ketiga $=-133956136,543$. Sedangkan bila $X_{1}$ (bagi hasil) $=1$, maka dana pihak ketiga akan mengalami kenaikan sebesar 448,585. Jadi semakin tinggi $\mathrm{X}_{1}$ (bagi hasil), maka dana pihak ketiga semakin tinggi.

- Regresi Parsial X2 (Pendapatan Per Kapita) terhadap Y (Dana Pihak Ketiga)

Tabel 4. Analisis Regresi $\left(\mathbf{X}_{2}\right)$

Coefficients $^{\mathrm{A}}$

\begin{tabular}{|cc|c|c|c|}
\hline \multirow{2}{*}{ Model } & \multicolumn{2}{|c|}{ Unstandardized Coefficients } & $\begin{array}{c}\text { Standardized } \\
\text { Coefficients }\end{array}$ \\
\cline { 3 - 5 } & & B & Std. Error & Beta \\
\hline \multirow{2}{*}{1} & $\begin{array}{c}\text { (Constant) } \\
\text { PP }\end{array}$ & $-12895187,654$ & 10442965,189 & \\
& PP & 2,148 &, 103 &, 963 \\
\hline
\end{tabular}

a. Dependent Variable: DPK 
Berdasarkan hasil perhitungan pada tabel 4 di atas atau tabel coefficients dapat disusun dalam bentuk persamaan regresi $\mathrm{Y}=-12895187,654+2,148 \mathrm{x}$, konstanta $(\mathrm{a})=-12895187,654$. Bila $\mathrm{X}_{2}$ (pendapatan per kapita) $=0$, maka dana pihak ketiga $=-12895187,654$. Sedangkan bila $\mathrm{X}_{2}$ (pendapatan per kapita) $=1$, maka dana pihak ketiga akan mengalami kenaikan sebesar 2,148. Jadi semakin tinggi $\mathrm{X}_{2}$ (pendapatan per kapita), maka dana pihak ketiga semakin tinggi.

- Regresi berganda $\mathrm{X}_{1}$ (Bagi Hasil) dan $\mathrm{X}_{2}$ (Pendapatan Per Kapita) terhadap Y (Dana Pihak Ketiga)

Tabel 5. Analisis Regresi Berganda

Coefficients $^{\mathrm{a}}$

\begin{tabular}{|l|r|r|r|}
\hline Model & \multicolumn{2}{|c|}{ Unstandardized Coefficients } & $\begin{array}{c}\text { Standardized } \\
\text { Coefficients }\end{array}$ \\
& B & Std. Error & Beta \\
\hline (Constant) & 26391095,770 & 23103790,088 & \\
\hline PP & 2,434 &, 181 & 1,091 \\
BH & $-90,644$ & 47,978 &,- 153 \\
\hline
\end{tabular}

a. Dependent Variable: DPK

Berdasarkan hasil perhitungan pada tabel 5 di atas atau tabel coefficients dapat disusun dalam bentuk persamaan regresi $\mathrm{Y}=26391095,770+2,434+-90,644 \mathrm{x}$, konstanta $(\mathrm{a})=$ 26391095,770. Bila $X_{1}$ (bagi hasil) dan $X_{2}$ (pendapatan per kapita) $=0$, maka dana pihak ketiga $=26391095,770$. Sedangkan bila $X_{1}$ (bagi hasil) dan $X_{2}$ (pendapatan per kapita) $=1$, maka dana pihak ketiga akan mengalami kenaikan sebesar $26391095,770+2,434+-90,644=$ 26391007,54. Jadi semakin tinggi $X_{1}$ (bagi hasil) dan $X_{2}$ (pendapatan per kapita), maka dana pihak ketiga semakin tinggi.

\section{Koefisien Korelasi}

$\checkmark$ Hubungan Bagi Hasil $\left(\mathrm{X}_{1}\right)$ terhadap Dana Pihak Ketiga $(\mathrm{Y})$

Tabel 6. Koefisien Korelasi $X_{1}$ terhadap $Y$ Model Summary ${ }^{\mathrm{b}}$

\begin{tabular}{|l|l|r|r|r|}
\hline Model & \multicolumn{1}{|c|}{$\mathrm{R}$} & R Square & Adjusted R Square & Std. Error of the Estimate \\
\hline 1 &, $758^{\mathrm{a}}$ &, 575 &, 563 & 25558330,137 \\
\hline
\end{tabular}

a. Predictors: (Constant), BH

b. Dependent Variable: DPK

Hasil perhitungan koefesien korelasi dengan rumus korelasi product moment, diperoleh besarnya koefisien korelasi (r) sebesar 0,758, ini berarti hubungan antar kedua variabel kuat dan positif. Artinya bahwa peningkatan bagi hasil berpengaruh positif terhadap besarnya dana pihak ketiga. 
Tabel 7. Rangkuman Hasil Analisis Koefisien Korelasi antara Bagi Hasil dan Dana Pihak Ketiga

\begin{tabular}{|c|c|c|c|}
\hline \multirow{2}{*}{$\mathrm{N}$} & \multirow{2}{*}{$\mathrm{r}_{\mathrm{y} 1}$} & \multicolumn{2}{|c|}{ Tabel } \\
\cline { 3 - 4 } & & $\alpha 0,05$ & $\alpha 0,01$ \\
\hline 36 & $0,758^{* *}$ & 0,329 & 0,424 \\
\hline
\end{tabular}

Ket: Hubungan $\mathrm{X}_{1}$ ke $\mathrm{Y}$ sangat signifikan $\mathrm{r}_{\text {hitung }} 0,758>\mathrm{r}_{\text {tabel }} 0,329$ dari $\alpha 0,05 * *$ Signifikan

- HubunganPendapatan Per Kapita $\left(\mathrm{X}_{2}\right)$ terhadap Dana Pihak Ketiga (Y)

Tabel 8. Koefisien Korelasi $X_{2}$ terhadap $Y$ Model Summary ${ }^{\mathbf{b}}$

\begin{tabular}{|l|r|r|r|r|}
\hline Model & R & R Square & Adjusted R Square & Std. Error of the Estimate \\
\hline 1 &, $963^{\mathrm{a}}$ &, 927 &, 925 & 10566586,855 \\
\hline
\end{tabular}

a. Predictors: (Constant), PP

b. Dependent Variable: DPK

Hasil perhitungan koefesien korelasi dengan rumus korelasi product moment, diperoleh besarnya koefisien korelasi (r) sebesar 0,963, ini berarti hubungan antar kedua variabel sangat kuat dan positif. Artinya bahwa peningkatan pendapatan per kapita berpengaruh positif terhadap besarnya dana pihak ketiga.

Tabel 9. Rangkuman Hasil Analisis Koefisien Korelasi antara Pendapatan Perkapita dan Dana Pihak Ketiga

\begin{tabular}{|c|c|c|c|}
\hline $\mathrm{N}$ & ry2 & \multicolumn{2}{|c|}{ Tabel } \\
\hline & & $\alpha 0,05$ & $\alpha 0,01$ \\
\hline 36 & $0,963^{* *}$ & 0,329 & 0,424 \\
\hline
\end{tabular}

Ket: Hubungan $\mathrm{X}_{2}$ ke $\mathrm{Y}$ sangat signifikan $\mathrm{r}_{\text {hitung }} 0,758>\mathrm{r}_{\text {tabel }} 0,329$ dari $\alpha 0,05 * *$ Signifikan.

- Hubungan Bagi Hasil $\left(\mathrm{X}_{1}\right)$ dan Pendapatan Per Kapita $\left(\mathrm{X}_{2}\right)$ terhadap Dana Pihak Ketiga (Y)

Tabel 10. Koefisien Korelasi $X_{1}$ dan $X_{2}$ terhadap $Y$ Model Summary ${ }^{\mathrm{b}}$

\begin{tabular}{|l|r|r|r|r|}
\hline Model & R & R Square & Adjusted R Square & Std. Error of the Estimate \\
\hline 1 &, $967^{\mathrm{a}}$ &, 934 &, 930 & 10188607,565 \\
\hline
\end{tabular}

a. Predictors: (Constant),BH, PP

b. Dependent Variable: DPK 
Hasil perhitungan koefesien korelasi dengan rumus korelasi product moment, diperoleh besarnya koefisien korelasi (r) sebesar 0,967, ini berarti hubungan antar ketiga variabel sangat kuat dan positif. Artinya bahwa peningkatan bagi hasil dan pendapatan per kapita berpengaruh positif terhadap besarnya dana pihak ketiga.

Tabel 11. Rangkuman Hasil Analisis Koefisien Korelasi antara Bagi Hasil, Pendapatan Perkapita dan Dana Pihak Ketiga

\begin{tabular}{|c|c|c|c|}
\hline \multirow{2}{*}{$\mathrm{N}$} & \multirow{2}{*}{ ry1 $2^{2}$} & \multicolumn{2}{|c|}{ Tabel } \\
\cline { 3 - 4 } & & $\alpha 0,05$ & $\alpha 0,01$ \\
\hline 36 & $0,967 * *$ & 0,329 & 0,424 \\
\hline
\end{tabular}

Ket: Hubungan $\mathrm{X}_{1}$ dan $\mathrm{X}_{2}$ ke $\mathrm{Y}$ sangat signifikan $\mathrm{r}_{\text {hitung }} 0,758>\mathrm{r}_{\text {tabel }} 0,329$ dari $\alpha$ $0,05 * *$ Signifikan

\section{Koefisien Determinasi}

Uji koefisien determinasi menunjukan presentase pengaruh semua variabel independen terhadap variabel dependen. Besarnya koefisien determinasi dari 0 sampai dengan 1.

૫ Pengaruh Bagi Hasil $\left(\mathrm{X}_{1}\right)$ terhadap Dana Pihak Ketiga (Y)

Tabel 12. Koefisien Determinasi $X_{1}$ terhadap $Y$ Model Summary ${ }^{b}$

\begin{tabular}{|l|r|r|r|r|}
\hline Model & R & R Square & Adjusted R Square & Std. Error of the Estimate \\
\hline 1 &, $758^{\mathrm{a}}$ &, 575 &, 563 & 25558330,137 \\
\hline
\end{tabular}
a. Predictors: (Constant), BH
b. Dependent Variable: DPK

Berdasarkan tabel di atas nilai $R$ Square (koefisien determinasi) sebesar 0,575, artinya presentase sumbangan pengaruh variabel bagi hasil terhadap dana pihak ketiga sebesar 57,5\% sedangkan sisanya $42,5 \%$ dipengaruhi oleh variabel lain yang belum dianalisis dalam penelitian ini.

$\square$ Pengaruh Pendapatan Per Kapita $\left(\mathrm{X}_{2}\right)$ terhadap Dana Pihak Ketiga (Y)

\section{Tabel 13. Koefisien Determinasi $X_{2}$ terhadap $Y$} Model Summary ${ }^{b}$

\begin{tabular}{|l|c|r|r|r|}
\hline Model & R & R Square & Adjusted R Square & Std. Error of the Estimate \\
\hline &, $963^{\mathrm{a}}$ &, 927 &, 925 & 10566586,855 \\
& & & \\
\hline
\end{tabular}
a. Predictors: (Constant), PP
b. Dependent Variable: DPK

Berdasarkan tabel 13 di atas nilai $R$ Square (koefisien determinasi) sebesar 0,927, artinya presentase sumbangan pengaruh variabel pendapatan per kapita terhadap dana pihak ketiga sebesar $92,7 \%$ sedangkan sisanya 7,3\% dipengaruhi oleh variabel lain yang belum dianalisis dalam penelitian ini. 
$\checkmark$ Pengaruh Bagi Hasil $\left(\mathrm{X}_{1}\right)$ dan Pendapatan Per Kapita $\left(\mathrm{X}_{2}\right)$ terhadap Dana Pihak Ketiga

(Y)

Tabel 14. Koefisien Determinasi $X_{1}$ dan $X_{2}$ terhadap $Y$ Model Summary ${ }^{b}$

\begin{tabular}{|l|c|r|r|r|}
\hline Model & $\mathrm{R}$ & R Square & Adjusted R Square & Std. Error of the Estimate \\
\hline 1 &, $967^{\mathrm{a}}$ &, 934 &, 930 & 10188607,565 \\
\hline
\end{tabular}
a. Predictors: (Constant), BH, PP
b. Dependent Variable: DPK

Berdasarkan tabel 14 di atas nilai $R$ Square (koefisien determinasi) sebesar 0,934, artinya presentase sumbangan pengaruh variabel bagi hasil dan pendapatan per kapita terhadap dana pihak ketiga sebesar 93,4\% sedangkan sisanya 6,6\% dipengaruhi oleh variabel lain yang belum dianalisis dalam penelitian ini.

Hasil penelitian ini bertentangan dengan hasil penelitian (Wibowo, 2011) yang meneliti faktor-faktor yang mempengaruhi jumlah dana pihak ketiga (DPK) pada bank syariah di Indonesia, dengan variabel bebas terdiri dari nisbah (profit sharing ratio), tingkat pembiayaan bermasalah (Non Performing Financing/NPF), dan pendapatan nasional riil (GDP riil) dengan tiga sampel penelitian yaitu Bank Muamalat Indonesia, Bank Syariah Mandiri dan Bank Mega Syariah. Dimana hasil penelitian (Wibowo, 2011) menunjukkan bahwa variabel nisbah (profit sharing ratio) tidak berpengaruh secara signifikan terhadap pertumbuhan dana pihak ketiga pada Bank Syariah di Indonesia, dan pendapatan nasional riil (GDP riil) yang mencerminkan kemampuan untuk menabung juga menunjukkan tidak adanya hubungan yang signifikan terhadap pertumbuhan dana pihak ketiga pada Bank Syariah di Indonesia.

Hasil penelitian ini mendukung hasil penelitian (Friska Diaz Sekar Puri, 2013) yang mengkaji faktor-faktor yang mempengaruhi penghimpunan Dana Pihak Ketiga (DPK) Perbankan Syariah di Indonesia dengan menggunakan data empiris selama periode 20082011. Berdasarkan estimasi persamaan, didapatkan informasi bahwa masyarakat menyimpan dananya di perbankan syariah dipengaruhi secara signifikan oleh Suku Bunga (SBI). Ini berarti nasabah yang ada di bank syariah sebagian besar adalah nasabah rasional. Pengaruh pendapatan juga memberikan hasil yang signifikan terhadap penghimpunan dana pihak ketiga perbankan syariah di Indonesia. Hal ini juga menunjukkan bahwa nasabah perbankan syariah juga mempunyai motif transaksional. Dengan demikian dikatakan bahwa nisbah bagi hasil dan pendapatan perkapita mempengaruhi masyarakat menyimpan dananya di perbankan syariah.

Hasil penelitian ini juga mendukung penelitian (Yuliana, 2009) tentang pengaruh bagi hasil, inflasi, Produk Domestik Bruto, dan Return on Investment (ROI) terhadap Dana Pihak Ketiga Perbankankan Syariah Tahun 2006 - 2008, dengan populasi seluruh bank yang berbasis syariah. Hasil penelitian menunjukkan bahwa secara parsial variabel bagi hasil berpengaruh positif dan signifikan terhadap Dana Pihak Ketiga Perbankan Syariah tahun 2006 - 2008; variabel ROI berpengaruh negatif dan signifikan terhadap Dana Pihak Ketiga Perbankan 
Syariah tahun 2006 - 2008; variabel inflasi berpengaruh negatif dan tidak signifikan terhadap

Dana Pihak Ketiga Perbankan Syariah tahun 2006 - 2008. Pada uji F menunjukkan bahwa variabel independen bagi hasil, inflasi, Produk Domestik Bruto, dan Return on Investment (ROI) berpengaruh positif dan signifikan terhadap Dana Pihak Ketiga Perbankankan Syariah Tahun $2006-2008$.

\section{KESIMPULAN}

Bagi hasil, Pendapatan Per Kapita dan Dana Pihak Ketiga di Bank Jabar Banten Syariah KCP Singaparna mengalami kenaikan dalam waktu tertentu.

Pengaruh Bagi Hasil terhadap Dana Pihak Ketiga Bank Jabar Banten Syariah KCP Singaparna sebesar 57,5\%. Hal ini dibuktikan dengan hasil pengolahan uji hipotesis secara parsial bahwa terdapat pengaruh yang signifikan antara Bagi Hasil terhadap Dana Pihak Ketiga yang ditunjukan oleh nilai ${ }_{\text {rhitung }}>_{\text {rtabel, }}$ atau 0,758 > 0,329.

Pengaruh Pendapatan Per Kapita terhadap Dana Pihak Ketiga Bank Jabar Banten Syariah KCP Singaparna sebesar 92,7\%. Hal ini dibuktikan dengan hasil pengolahan uji hipotesis secara parsial bahwa terdapat pengaruh yang signifikan antara Pendapatan Per

Kapita terhadap Dana Pihak Ketiga yang ditunjukan oleh nilai $r_{\text {hitung }}>r_{\text {tabel }}$ atau 0,963 > 0,329. Pengaruh Bagi Hasil dan Pendapatan Per Kapita secara bersama-sama terhadap Dana Pihak Ketiga Bank Jabar Banten Syariah KCP Singaparna sebesar 93,4\%, sedangkan sisanya 6,6\% dipengaruhi oleh variabel lain yang belum dianalisis dalam penelitian ini.

\section{REFERENSI}

Eliza Fitriah, \& Nur S. Buchori. (t.t.). Pengaruh Nisbah Bagi Hasil terhadap Penghimpunan Dana Bank Syariah (Studi Kasus Pada Produk Tabungan di BPR Syariah Kota Bekasi), di akses pada tanggal 21 Januari 2015. 10:43 AM.

Friska Diaz Sekar Puri. (2013). Faktor-faktor yang Mempengaruhi Dana Pihak Ketiga Pada Perbankan Syariah (Indonesia, 2008-2011). [Yogyakarta] : Universitas Gadjah Mada.

Kasmir. (2004). Manajemen Perbankan. Jakarta: PT. Raja Grafindo.

Lincolin Arsyad. (2004). Ekonomi Pembangunan. Yogjakarta: Sekola Ilmu Ekonomi YKPN.

Muhamad. (2001). Teknik Perhitungan Bagi Hasil di Bank Syariah. Yogjakarta: UII Press.

Muhammad. (2014). Manajemen Dana Bank Syariah. Jakarta: Raja Grafindo Persada.

Putu Semaradana. (t.t.). Konsumsi, Tabungan, dan investasi

[Https://maradana.files.wordpress.com]. 
Safarul Aufa. (t.t.). Pengaruh Pendapatan Perkapita, Pertumbuhan Penduduk, Dan Tingkat Upah Terhadap Biaya Hidup Di Indonesia.

Sugiyono. (2013). Metode Penelitian. Bandung: ALFABETA.

Wibowo, I. (2011). Analisis Faktor-Faktor Yang Mempengaruhi Jumlah Dana Pihak Ketiga (DPK) pada Bank Syariah di Indonesia. Universitas Negeri Malang.

wijaya. (t.t.). Teori Ekonomi Keynes. Diambil dari wijayanomics website: https://wijayanomics.wordpress.com

Yuliana. (2009). Faktor-Faktor yang Mempengaruhi Dana Pihak Ketiga pada Bank Syariah Tahun 2006 - 2008. UIN Suna Kalijaga Yogyakarta. 